\title{
PENGARUH MOTIVASI BELAJAR SISWA TERHADAP KEMAMPUAN PEMECAHAN MASALAH MATEMATIKA SISWA DI KELAS VIII MTSN 3 AGAM TAHUN PELAJARAN 2018/2019
}

\author{
Azizah Tri Rahmah ${ }^{1}$, Aniswita ${ }^{1}$, Haida Fitri ${ }^{1}$ \\ ${ }^{1}$ Institut Agama Islam Negeri Bukittinggi, Jl. Gurun Aua, Kubang Putiah, Kota Bukittinggi 26117, Indonesia \\ Email: azizahtrirahma97@gmail.com
}

\begin{abstract}
Abstrak
Penelitian ini dilatarbelakangi oleh hasil observasi dan wawancara peneliti di MTsN 3 Agam, kurangnya motivasi belajar siswa, hal ini dilihat dari kehadiran siswa dan partisipasi siswa dalam belajar. Kemudian rendahnya kemampuan pemecahan masalah matematika siswa, hal ini dilihat dari nilai ulangan tengah semester 2 pada pelajaran matematika. Rendahnya kemampuan pemecahan masalah matematika siswa juga disebabkan oleh beberapa faktor salah satunya rendahnya motivasi belajar matematika siswa terhadap pelajaran matematika. Penelitian ini menggunakan penelitian Expost Facto. Populasi penelitian adalah kelas VIII MTsN 3 Agam Tahun Pelajaran 2018/2019 dan sampel penelitian diambil secara random sampling yang terdiri dari 34 orang siswa yang diambil dari total populasi yang berjumlah 168 orang siswa. Penelitian menggunakan uji Z. Uji Z digunakan untuk mencari uji kebermaknaan regresi. Persamaan regresi sederhana untuk motivasi belajar siswa terhadap kemampuan pemecahan masalah matematika adalah $\mathrm{Y}=0,05+0,29 \mathrm{X}$ dengan korelasi 0,68 dan KD sebesar 48,78\%. Hasil pengujian hipotesis diperoleh Zhitung > Ztabel yaitu $5,80>1,96$. Dapat disimpulkan bahwa terdapat pengaruh yang signifikan antara motivasi belajar siswa terhadap kemampuan pemecahan masalah matematika siswa di Kelas VIII MTsN 3 Agam Tahun Pelajaran $2018 / 2019$.
\end{abstract}

Kata kunci: Motivasi Belajar, Kemampuan Pemecahan Masalah

\begin{abstract}
This research is motivated by the results of interviews and observations of researchers at MTsN 3 Agam, lack of student learning motivation, this is seen from the presence of students and student participation in learning. Then the low mathematical problem solving abilities of students, this is seen from the middle semester 2 test scores on mathematics. The low level of mathematical problem solving abilities of students is also caused by several factors, one of which is the low motivation of students' mathematics learning towards mathematics. This research uses Expost Facto research. The study population was class VIII MTsN 3 Agam Academic Year 2018/2019 and the study sample was taken by random sampling consisting of 34 students taken from a total population of 168 students. The study used the $\mathrm{Z}$ test. The $\mathrm{Z}$ test was used to find the regression significance test. The simple regression equation for student learning motivation towards mathematical problem solving ability is $\mathrm{Y}=0.05+0.29 \mathrm{X}$ with a correlation of 0.68 and $\mathrm{KD}$ of $48.78 \%$. The results of hypothesis testing obtained Zhitung> Ztable which is 5.80> 1.96. It can be concluded that there is a significant effect of students' learning motivation on mathematical problem solving abilities of students in Class VIII MTsN 3 Agam Academic Year 2018/2019.
\end{abstract}

Keywords: Learning Motivation, Problem Solving Abilities

\section{PENDAHULUAN}

Salah satu mata pelajaran di sekolah yang dipelajari oleh siswa adalah matematika. Matematika penuh dengan konsep dan prinsip, dimana dalam menyelesaikan materi matematika diperlukan suatu kemampuan untuk memahami permasalahan tersebut kemudian mengkonstruksikan dalam bentuk ide-ide matematika dan menyelesaikan ide tersebut sesuai dengan konsep dan prinsip matematika. Menurut peraturan Menteri Pendidikan dan Kebudayaan Republik Indonesia Nomor 58 tahun 2014 pada lampiran IV tentang Matematika menjelaskan tujuan pembelajaran matematika yaitu: Memiliki sikap menghargai kegunaan matematika dalam kehidupan, yaitu memiliki rasa ingin tahu, perhatian, dan minat dalam mempelajari matematika, serta sikap ulet dan percaya diri dalam pemecahan masalah. Salah satu tujuan dari pembelajaran matematika di atas adalah memecahkan 
masalah. Pemecahan masalah merupakan sarana sekaligus target dari pembelajaran matematika disekolah. Menurut polya dalam Dian fitri Argarini indikator pemecahan masalah adalah sebagai berikut : (1) Pemahaman masalah; (2) Perencanaan strategi; (3) Pelaksanaan strategi; (4) Pengecekan kembali. (Angraini, 2018)

Dalam pemecahan masalah sangat dibutuhkan motivasi belajar. Hakekat motivasi belajar adalah dorongan internal dan eksternal pada siswa-siswa yang sedang belajar untuk mengadakan perubahan tingkah laku, pada umumnya dengan beberapa indikator atau unsur yang mendukung. Indikator motivasi belajar dapat diklasifikasikan sebagai berikut: (1) adanya hasrat dan keinginan berhasil; (2) adanya dorongan dan kebutuhan dalam belajar; (3) adanya harapan dan cita-cita masa depan; (4) adanya penghargaan dalam belajar; (5) adanya kegiatan yang menarik dalam belajar; (6) adanya lingkungan belajar yang kondusif, sehingga memungkinkan seseorang siswa dapat belajar dengan baik. (B.Uno, 2010)

Berdasarkan indikator motivasi belajar tersebut maka motivasi akan menyebabkan terjadinya suatu perubahan energi yang ada pada diri manusia sehingga berhubungan dengan persoalan gejala kejiwaan, perasaan dan juga emosi, untuk kemudian bertindak atau melakukan sesuatu. Semua ini didorong karena adanya tujuan, kebutuhan dan keinginan. Dari kenyataan tersebut membuktikan betapa pentingnya motivasi belajar.

Berkaitan dengan kemampuan pemecahan masalah sebagian besar pembelajaran matematika di sekolah melibatkan kemampuan pemecahan masalah. Bila kemampuan pemecahan masalah siswa tidak dikembangkan maka bagi siswa matematika hanya akan menjadi materi yang mengikuti serangkaian prosedur dan meniru contoh-contoh tanpa mengetahui maknanya. Di samping itu karena pemecahan masalah itu salah satu dari tujuan pembelajaran matematika maka pemecahan masalah itu menjadi salah satu bentuk hasil dari belajar. Dalam pemecahan masalah matematika motivasi belajar merupakan unsur penting yang harus dimiliki oleh siswa, siswa yang mempunyai motivasi belajar yang tinggi akan tekun dalam mengerjakan tugas, ulet dan pantang menyerah dalam memecahkan berbagai masalah dan hambatan, menaruh minat terhadap proses pembelajaran, memikirkan pemecahan masalah khususnya yang berkaitan dengan masalah matematika.

Penelitian Muzaki pada tahun 2010 dalam Himmatul Ulya memperoleh hasil bahwa kreativitas dan motivasi belajar siswa memberikan pengaruh yang signifikan terhadap kemampuan siswa menyelesaikan masalah. Hal ini menunjukkan bahwa jika siswa memiliki kreativitas dan motivasi belajar yang tinggi maka kemampuan siswa dalam menyelesaikan masalah juga akan baik (Ulya, n.d.) Untuk melihat kemampuan pemecahan masalah siswa maka penulis memberikan satu soal tes yang memuat kemampuan pemecahan masalah dan diskor berdasarkan rubrik penskoran pemecahan masalah. Salah satu soal tes yang penulis berikan memenuhi indikator pemecahan masalah matematika adalah sebagai berikut:

Farel adalah seorang atlet pelari, Farel akan berlatih karena akan mengikuti pertandingan pekan depan, dalam latihannya Farel berlari mengelilingi lapangan dengan jalur berbentuk lingkaran, Farel mengelilingi lapangan sebanyak 7 kali. Jarak Farel dengan titik tengah lingkaran adalah $6400 \mathrm{~m}$. Tentukan jarak yang ditempuh Farel untuk menyelesaikan latihannya, dan diperoleh hasil sebagai berikut.

Tabel 1.1Hasil UTS Tes Kemampuan Pemecahan Masalah Matematika siswa kelas VIII MTsN 3 Agam.

\begin{tabular}{|c|c|c|c|c|c|}
\hline Kelas & \multirow{2}{*}{$\begin{array}{c}\text { Jumlah } \\
\text { siswa }\end{array}$} & \multicolumn{2}{|c|}{$\begin{array}{c}\text { Nilai kemampuan } \\
\text { pemecahan masalah }\end{array}$} & \multicolumn{2}{|c|}{ Persentase } \\
\cline { 3 - 6 } & & $\geq 55$ & $<55$ & $\geq 55$ & $<55$ \\
\hline VIII.1 & 32 orang & 8 orang & 24 orang & $25,00 \%$ & $75,00 \%$ \\
\hline VIII.2 & 34 orang & 11 orang & 23 orang & $32,35 \%$ & $67,65 \%$ \\
\hline VIII.3 & 33 orang & 8 orang & 25 orang & $24,24 \%$ & $75,76 \%$ \\
\hline VIII.4 & 34 orang & 9 orang & 25 orang & $26,47 \%$ & $73,53 \%$ \\
\hline VIII.5 & 35 orang & 7 orang & 28 orang & $20,00 \%$ & $80 \%$ \\
\hline
\end{tabular}

Sumber : Guru mata pelajaran matematika MTsN 3 Agam

Berdasarkan uraian Tabel 1.1 diperoleh siswa yang di atas cukup (lebih dari 55) berkisar dari 20,00\% sampai 32,35\% dan siswa yang di bawah cukup (kurang dari 55) berkisar dari 67,65\% sampai $80,00 \%$. Diduga penyebab rendahnya hasil tes kemampuan pemecahan masalah matematika dari 
siswa adalah siswa hanya berfokus pada contoh soal yang di berikan guru saja, jika soal sudah ditukar maka siswa sudah tidak paham lagi dengan soal tersebut karena siswa belum bisa memahami apa yang di sebutkan didalam soal, siswa sulit untuk mengerjakannya karena iswa kurang memahami soal dan bagaimana cara menyelesaikannya.

Di sampng itu penulis juga menemukan fenomena lain yang menarik, dimana ada siswa yang indikasi motivasinya rendah memiliki kemampuan pemecahan masalah yang tinggi dan sebaliknya. Diketahui bahwa siswa dengan inisial (MR) pernah sakit, sering alfa, dan sering cabut dikelas juga sering berbicara dengan temannya justru mendapatkan nilai yang tinggi dan kemampuan pemecahan masalah yang juga tinggi, setelah dilakukan wawancara dengan MR, ia mengatakan bahwa pernah Alfa karena telat bangun, dan Cabut karena tidak membuat PR, kemudian siswa dengan inisial (SS) setiap pembelajaran matematika dia selalu mengikutinya, selalu membuat PR dan mengumpulkan tugas tepat waktu, tidak pernah absen saat belajar dan penilaian sikapnya juga baik namun mendapatkan nilai yang rendah, begitupun dengan kemampuan pemecahan masalahnya juga rendah, hal ini tidak sesuai dengan kehadiran dan sikapnya, setelah dilakukan wawancara SS mengatakan bahwa ia sulit untuk memahami pelajaran dan soal-soal matematika apalagi soal dalam bentuk soal cerita. Dan siswa lainnya dikelas tersebut rata-rata juga memiliki kemampuan pemecahan masalah matematika yang masih kurang bagus. Permasalahan itu merupakan sebuah indikasi kurangnya motivasi belajar siswa.

\section{METODE PENELITIAN}

Berdasarkan permasalahan dan kajian teori yang diuraikan pada bab 1 dan bab 2 maka jenis penelitian yang dilakukan adalah penelitian regresi. Analisis regresi merupakan salah satu analisis yang bertujuan untuk mengetahui pengaruh suatu variabel lain (Thoifah, 2015) Sifat penelitian ini adalah ex-postfacto. Penelitian ex-postfacto merupakan penelitian dimana variabel-variabel bebas telah terjadi ketika peneliti mulai dengan pengamatan variabel terikat dalam suatu penelitian (Sukardi, 2008) Subjek penelitiannya adalah seluruh siswa kelas seluruh siswa kelas VIII MTsN 3 Agam Tahun Pelajaran 2018/2019 yang berjumlah 168 orang siswa. Berdasarkan informasi dari pihak sekolah kelas tersebut adalah kelas yang mempunyai kemampuan berbeda-beda atau heterogen. Teknik pengumpulan data yang digunakan dalam penelitian ini adalah Tes tertulis dan angket. Tes yang peneliti gunakan dalam penelitian ini adalah soal tes berupa uraian yaitu tes yang digunakan untuk mengukur tingkat kemampuan pemecahan masalah siswa dan angket untuk mengetahui seberapa motivasi siswa belajar matematika. Teknik analisis data bertujuan untuk memperoleh makna dari data yang telah terkumpul. Analisis yang dilakukan adalah analisis regresi, analisis regresi sederhana digunakan hanya untuk satu variabel bebas (independent) dan satu variabel tak bebas (dependent).

Dengan rumus:

$Y=a+b . X$

Keterangan:

$\mathrm{Y}=$ = variabel tak bebas (terikat)

$\mathrm{X} \quad=$ variabel bebas

Rumus yang digunakan untuk mencari nilai konstanta $a$ dan $b$ adalah:

$$
\begin{gathered}
a=\frac{\sum Y-b \sum X}{n} \\
b=\frac{n \cdot \sum X Y-\sum X \cdot \sum Y}{n \cdot \sum X^{2}-\left(\sum X\right)^{2}}
\end{gathered}
$$

Keterangan:

$\mathrm{n}=$ jumlah data (Siregar, 2014) 


\section{HASIL PENELITIAN DAN PEMBAHASAN}

\section{A. Hasil Penelitian}

\section{Data Motivasi Belajar Siswa}

Data tentang motivasi belajar dikumpulkan menggunakan angket yang peneliti sebarkan kepada sampel penelitian sebanyak 34 orang siswa kelas VIII MTsN 3 Agam. Angket disebarkan menggunakan skala liker yang terdiri dari pernyataan positif dan negatif, dengan memilih salah satu alternatif jawaban Sangat Sesuai (Ss), Sesuai (S), Ragu-ragu (Rr), Tidak Sesuai (Ts), Sangat Tidak Sesuai (Sts). Untuk pernyataan positif diberi skor yaitu: $\mathrm{Ss}=5, \mathrm{~S}=4, \mathrm{Rr}=3$, Ts=2, $\mathrm{Sts}=1$. Sedangkan untuk pernyataan negatif diberi skor yaitu $S s=1, S=2, R r=3, T s=4$, $S t s=5$. Jumlah pernyataan pada angket motivasi belajar sebanyak 37 item dengan skala (1-5) rentang skor (37-185)

Tabel 4.1: Deskripsi Data Motivasi Belajar Siswa

\begin{tabular}{|l|l|}
\hline Deskripsi & Nilai \\
\hline Nilai Maksimum & 175 \\
\hline Nilai Minimum & 85 \\
\hline Mean & 125,44 \\
\hline Standar Deviasi & 23,056 \\
\hline Modus & 90 \\
\hline Median & 125,00 \\
\hline
\end{tabular}

Dari angket yang terdiri dari 37 item dengan skala 1-5, maka rentangan skor yang ditetapkan untuk instrumen motivasi belajar matematika adalah $37-185$. Dan rata-rata skor teoritik (Mean ideal - Mi) adalah 45 dan standar deviasi (standar deviasi ideal - Sdi ) adalah 15. Berdasarkan data penelitian dapat diketahui bahwa skor terendah 85 dan skor tertinggi 175. Menurut hasil perhitungan didapatkan rata-rata (mean) sebesar 125,44, simpangan baku (standar deviasi ) sebesar 23.056, modus (mode) sebesar 90, nilai tengah (median) sebesar 125,00 .Dari data tersebut menunjukkan bahwa skor rata-rata data sebesar 114,9412 .

\section{Data kemampuan pemecahan masalah matematika siswa}

Data kemampuan pemecahan masalah matematika siswa diperoleh melalui pengisian intrumen penelitian berupa Tes pada 34 orang siswa kelas VIII MTsN 3 Agam.

Tabel 4.2: Deskripsi Data Tes Kemampuan Pemecahan Masalah Matematika Siswa

\begin{tabular}{|l|l|}
\hline Deskripsi & Nilai \\
\hline Nilai Maksimum & 95 \\
\hline Nilai Minimum & 5 \\
\hline Mean & 36,3235 \\
\hline Standar Deviasi & 21,7531 \\
\hline Modus & 35 \\
\hline Median & 35 \\
\hline
\end{tabular}

Rentangan skor yang ditetapkan untuk tes kemampuan pemecahan masalah adalah 0-100. Dan rata-rata secara teoritik (mean ideal - mi) adalah 45 dan standar deviasi (standar deviasi ideal - Sdi) adalah 15. Berdasarkan data penelitian dapat diketahui bahwa nilai terendah 5 dan nilai tertinggi 95. Menurut hasil perhitungan didapatkan rata-rata (mean) sebesar 36,32, simpangan baku (standar deviasi) sebesar 21,75, modus (mode) sebesar 35, dan nilai tengah (median) sebesar 35. Dari data tersebut menunjukkan bahwa skor rata-rata data 36,32 lebih rendah dibandingkan skor rata-rata teoritik 45. Ini berarti kemampuan pemecahan masalah matematika siswa tergolong rendah. 


\section{Uji Normalitas}

\begin{tabular}{|c|c|c|}
\hline Variabel & L0 & Ltabel \\
\hline Motivasi Belajar & 0,07806 & 0,1497 \\
\hline $\begin{array}{c}\text { Kemampuan } \\
\text { Pemecahan Masalah } \\
\text { Matematika }\end{array}$ & 0,04552 & 0,1497 \\
\hline
\end{tabular}

\section{Uji linieritas Regresi}

Berdasarkan hasil perhitungan manual uji linier untuk nilai $\mathrm{F}_{\text {hitung }}$ didapatkan nilai $\mathrm{F}_{\text {hitung }}$ lebih besar dari nilai $\mathrm{F}_{\text {tabel }}$ dimana $\mathrm{F}_{\text {hitung }}>\mathrm{F}_{\text {tabel }}=30,48>4,13$ maka $\mathrm{H}_{0}$ ditolak dan $\mathrm{H}_{1}$ diterima, dapat disimpulkan bahwa motivasi belajar terhadap kemampuan pemecahan masalah matematika berpola linier.

\section{Koefisien Korelasi Sederhana}

Setelah dilakukan perhitungan didapat hubungan antara motivasi belajar dengan kemampuan pemecahan masalah matematika yaitu 0,69 atau $r_{x y}=0,69$. Ini artinya hubungan motivasi belajar dengan kemampuan pemecahan masalah matematika kuat.

\section{Koefisien Determinasi Sederhana}

Koefisien korelasi $\mathrm{R}$ yang diperoleh pada hasil pengolahan data adalah 0,69 dengan nilai $\mathrm{R}$ squre atau koefisien determinasi (KD) yang menunjukkan seberapa bagus model regresi yang dibentuk oleh interaksi variabel bebas dan variabel terikat. Nilai KD yang diperoleh adalah $48,78 \%$ hal ini dapat ditafsirkan bahwa motivasi belajar (X) memiliki pengaruh kontribusi sebesar 48,78\% terhadap kemampuan pemecahan masalah matematika (Y).

\section{Pengujian regresi sederhana}

Berdasarkan hasil perhitungan didapatkan persamaan regresi sederhana untuk motivasi belajar yaitu $\mathrm{Y}$ $=0,05+0,29 \mathrm{X}$. Persamaan regresi tersebut dapat dijelaskan sebagai berikut :

a) Konstanta $\mathrm{a}=0,05$, artinya jika motivasi belajar siswa $(\mathrm{x})=5$, maka kemampuan pemecahan masalah matematika (y) nilainya juga positif yaitu 1,49. jika motivasi belajar siswa $(\mathrm{x})=-5$, maka kemampuan pemecahan masalah matematika (y) nilainya juga negatif yaitu $-1,39$.

b) Koefisien regresi variabel motivasi belajar (x) sebesar 0,29, artinya jika motivasi belajar siswa meningkat sebesar 0,24 , maka kemampuan pemecahan masalah matematika akan mengalami peningkatan sebesar 0,29. Koefisien bernilai positif artinya terjadinya hubungan positif antara motivasi belajar dengan kemampuan pemecahan masalah matematika siswa, semakin meningkat motivasi belajar siswa maka semakin meningkat kemampuan pemecahan masalah matematika siswa.

\section{Kebermaknaan regresi}

Berdasarkan hasil perhitungan kebermaknaan regresi untuk nilai $Z_{\text {hitung }}$ didapatkan nilai $Z_{\text {hitung }}$ lebih besar dari nilai $Z_{\text {tabel }}$ dimana $Z_{\text {hitung }}>Z_{\text {tabel }}=5,80>1,69$, maka $\mathrm{H}_{\mathrm{O}}$ ditolak dan $\mathrm{H}_{1}$ diterima, dapat disimpulkan bahwa "Terdapat hubungan yang signifikan motivasi belajar terhadap kemampuan pemecahan masalah matematika siswa".

\section{B. Pembahasan}

Setelah dilakukan deskripsi data dan analisis data maka didapatkan gambaran secara umum dari motivasi belajar, kemampuan pemecahan masalah matematika siswa, serta pengaruh motivasi belajar 
matematika siswa dengan kemampuan pemecahan masalah matematika. Motivasi belajar sangat berpengaruh terhadap kemampuan pemecahan masalah matematika siswa. Motivasi sebagai faktor utama dalam belajar yakni berfungsi menimbulkan, mendasari dan menggerakkan perbuatan belajar. Dengan motivasi siswa juga tekun dalam belajar, dengan motivasi juga siswa menjadi berminat dalam belajar matematika. Jika siswa sudah termotivasi untuk belajar matematika maka dengan itu bisa meningkatkan kemampuan pemecahan masalah matematika siswa menjadi lebih baik. Motivasi belajar siswa dikelas VIII MTsN 3 Agam tergolong sedang dan kemampuan pemecahan masalah matematika siswa kelas VIII MTsN 3 Agam masih tergolong rendah. Berikut ini beberapa hasil lembar jawaban siswa dalam mengerjakan soal tes kemampuan pemecahan masalah matematika

Soal nomor 1 yang mana siswa mendapatkan skor 10 dan 1, soalnya yaitu : Pelemparan 3 mata uang logam dilakukan dalam waktu yang sama, berapakah frekuensi harapan dari peluang munculnya paling sedikit 1 angka dari 30 kali pelemparan uang logam ?

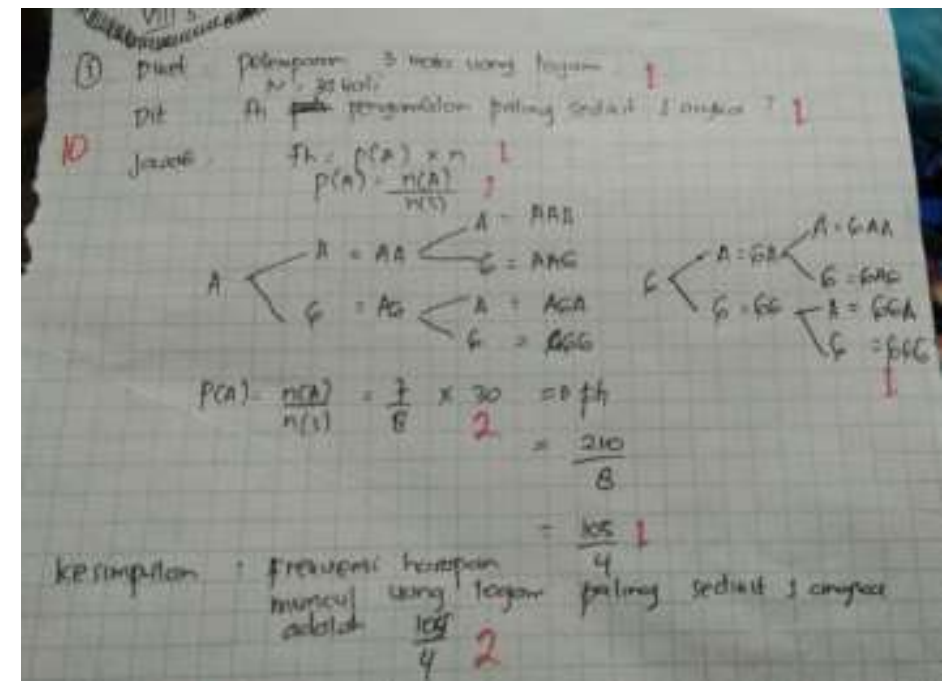

Gambar 4.1 : jawaban siswa berkemampuan pemecahan masalah tinggi

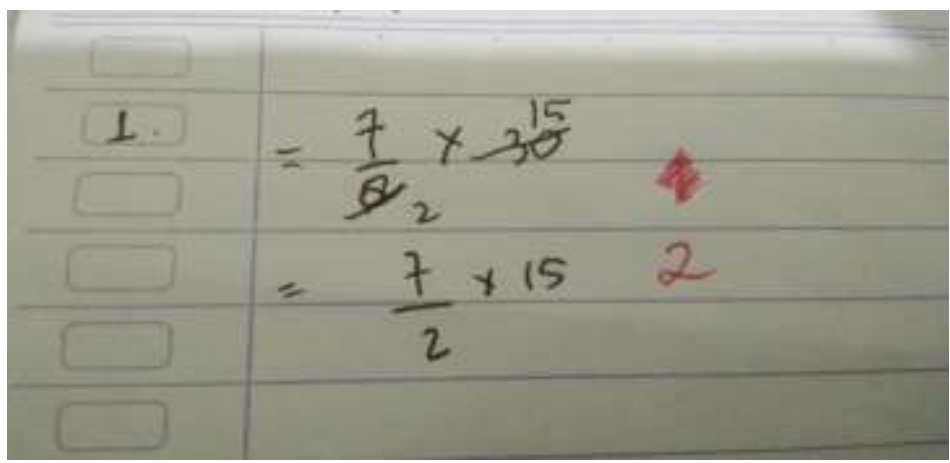

Gambar 4.2 : jawaban siswa berkemampuan pemecahan masalah rendah

Berdasarkan jawaban yang diberikan siswa untuk soal nomor 1 ini terlihat bahwa sebagian siswa memenuhi aspek kemampuan pemecahan masalah matematika, dimana pada gambar 4.5 siswa menuliskan apa yang diketahui dan ditanyakan, menuliskan perencanaan, melakukan perhitungan dan membuat kesimpulan. Kemudian pada gambar 4.6 terlihat bahwa siswa hanya melakukan perhitungan saja.

Hipotesis yang diajukan mengenai pengaruh motivasi belajar terhadap kemampuan pemecahan masalah matematika siswa kelas VIII MTsN 3 Agam menunjukkan terdapat pengaruh yang signifikan. Langkah pertama yang harus ditempuh terlebih dahulu adalah mencari df (degree of freedom) atau derajat kebebasan, dengan rumus $\mathrm{df}=\mathrm{N}-2$. Responden yang diteliti sebanyak 34 orang, dengan $\mathrm{N}=34$. Dapat diperoleh df-nya yaitu $\mathrm{df}=34-2=32$. Setelah diketahui $\mathrm{df}$ sebesar 32 
kemudian lihat pada tabel " $\mathrm{r}$ " product momen, maka dapat diketahui dengan df sebesar 32, diperoleh "r" product momen pada taraf signifikansi $5 \%=0,339$.

Berdasarkan hasil analisis korelasi sederhana, diperoleh nilai $\mathrm{r}_{\mathrm{xy}}=0,69846$ merupakan korelasi yang positif dan signifikan pada taraf $5 \%(0,69846>0,339)$. Besarnya $r_{x y}$ yang diperoleh terletak antara 0,61 - 0,80 maka korelasi antara variabel motivasi belajar dengan kemampuan pemecahan masalah matematika siswa kelas VIII MTsN 3 Agam tergolong tinggi. Dan untuk analisis kebermaknaan regresi diperoleh $Z_{\text {hitung }}=5,80 Z_{\text {tabel }}=4,13$. Harga $Z_{\text {hitung }}$ lebih besar dari $Z_{\text {tabel. }}$. Hal tersebut berarti hipotesis alternatif $\left(\mathrm{H}_{1}\right)$ diterima dan terbukti kebenarannya yaitu terdapat pengaruh yang signifikan motivasi belajar terhadap kemampuan pemecahan masalah matematika siswa dan hipotesis nihil $\left(\mathrm{H}_{0}\right)$ ditolak kebenarannya yaitu tidak terdapat pengaruh yang signifikan motivasi belajar terhadap kemampuan pemecahan masalah matematika siswa.

Sedangkan koefisien determinasi diperoleh sebesar 48,78\%. Artinya motivasi belajar siswa berpengaruh sebanyak $48,78 \%$ terhadap kemampuan pemecahan masalah matematika siswa sedangkan sisanya dipengaruhi oleh faktor lain. Variansi kemampuan pemecahan masalah matematika dapat dijelaskan melalui motivasi belajar. Sehingga meningkatnya motivasi belajar siswa dapat meningkatkan kemampuan pemecahan masalah matematika siswa. Sebagaimana yang telah diteliti oleh peneliti sebelumnya menyatakan terdapat pengaruh yang signifikan motivasi berprestasi siswa terhadap kemampuan siswa memecahkan masalah matematika, Artinya semakin tinggi motivasi berprestas siswa semakin tinggi pula kemampuan siswa dalam memecahkan masalah matematika. Dengan demikian, hasil pengujian menunjukkan menolak $\mathrm{H}_{0}$ dan disimpulkan bahwa variabel motivasi berprestasi berpengaruh signifikan terhadap kemampuan siswa memecahkan masalah matematika.

Hasil penelitian ini menguatkan teori bahwa menurut Slameto dalam Riski Apriyani salah satu komponen motivasi belajar adalah dorongan kognitif yang terdiri dari kebutuhan untuk mengetahui, kebutuhan untuk mengerti dan kebutuhan untuk memecahkan masalah dan dorongan kognitif ini timbul di dalam proses interaksi antara siswa dengan tugas atau masalah.

Hal ini menunjukkan bahwa tinggi rendahnya kemampuan pemecahan masalah matematika siswa dipengaruhi oleh motivasi belajar. Dengan adanya motivasi belajar siswa yang maksimal terhadap proses pembelajaran matematika, diharapkan dapat menunjang serta meningkatkan kemampuan pemecahan masalah matematika siswa. Dengan adanya motivasi maka siswa akan terdorong untuk lebih giat lagi dalam belajar serta meningkatkan kemampuannya dalam pemecahan masalah matematika.

\section{KESIMPULAN}

Berdasarkan hasil dan pembahasan yang telah dilakukan, diperoleh kesimpulan yaitu Terdapat pengaruh yang signifikan motivasi belajar siswa terhadap kemampuan pemecahan masalah matematika di kelas VIII MTsN 3 Agam.

\section{REFERENCES}

Angraini, D. F. (2018). Analisis pemecahan masalah masalah berbasis polya pada materi perkalian vektor ditinjau dari gaya belajar. Jurnal Pendidikan Matematika Dan Pelajaran, 6, 91-99.

B.Uno, H. (2010). Teori Motivasi dan Pengukurannya. Jakarta: Bumi Aksara.

Siregar, S. (2014). Statistik Parametik. Jakarta: PT Bumi Aksara.

Sukardi. (2008). Metodologi Penelitian pendidikan. Jakarta: Bumi Aksara.

Thoifah, I. anatut. (2015). Statistika Pendidikan dan Metode Penelitian Kuantitatif. Malang: Madani.

Ulya, H. (n.d.). Profil kemampuan pemecahan masalah siswa bermotivasi belajar tinggi. Jurnal Konseling GUSJIGANG, 2, 92. 
